\title{
Text Mining pada Sosial Media untuk Mendeteksi Emosi Pengguna Menggunakan Metode Support Vector Machine dan K-Nearest Neighbour
}

\author{
Dwi Ardiada ${ }^{1}$, Made Sudarma ${ }^{2}$, Dwi Giriantari ${ }^{3}$ \\ [Submission: 29-11-2018, Accepted: 31-03-2019]
}

\begin{abstract}
Twitter social networking and microblog services that allow users to send and read text-based messages up to 140 characters, known as tweets. A text on a tweet does not only convey information from an information, but also contains information about human behavior including emotions. To detect emotions from text on twitter social media services with unstructured data, one needs to do text analysis by using Text Mining.

In this study propose to conduct text mining research on Social Media to detect users' emotions. From the tests conducted using the Support Vector Machine and K-Nearest Neighbor method, it can produce an average precision value of 0.4564 . The recall value is 0.502 and the accuracy value is 0.8104 while the $K$ Nearest Neighbor method has an average precision value of 0.3421 . The recall value is 0.4595 and the accuracy value is 0.797 .

The results of testing with the SVM-KNN method have a significant increase in the value of the K-Nearest Neighbor method. SVM-KNN method also has a significant difference in computational time in doing two classifications rather than the K-Nearest Neighbor method which only does one classification.
\end{abstract}

Intisari- Twitter layanan jejaring sosial dan mikroblog yang memungkinkan penggunanya untuk mengirim dan membaca pesan berbasis teks hingga 140 karakter, yang dikenal dengan sebutan kicauan (tweet). Sebuah teks pada tweet tidak hanya menyampaikan keterangan dari suatu informasi, tetapi juga berisi informasi tentang perilaku manusia termasuk emosi. Untuk mendeteksi emosi dari teks pada layanan sosial media twitter dengan data yang tidak terstruktur maka perlu dilakukan analisis teks salah satunya dengan menggunakan Text Mining.

Pada penelitian ini mengusulkan melakukan penelitian text mining pada Sosial Media untuk mendeteksi emosi pengguna. Dari Pengujian yang dilakukan dengan metode Support Vector Machine dan K-Nearest Neighbour dapat menghasilkan nilai rata-rata precision sebesar 0.4564 . Nilai recall sebesar 0.502 dan pada nilai accuracy sebesar 0.8104 sedangkan dari metode $\mathrm{K}$ Nearest Neighbour nilai rata-rata precision sebesar 0.3421 . Nilai recall sebesar 0.4595 dan pada nilai accuracy sebesar 0.797 .

\footnotetext{
${ }^{1}$ Mahasiswa Pascasarjana, Teknik Elektro Fakultas Teknik Universitas Udayana, Jln. Jalan Kamps Bukit Jimbaran 80361 INDONESIA (telp: 0361-703315; fax: 0361-703315; e-mail: dwiardiada99@gmail.com )

2, 3 Dosen,Jurusan Teknik Elektro dan Komputer Fakultas Teknik Universitas Udayana, Jln. Jalan Kampus Bukit Jimbaran 80361 INDONESIA (telp: 0361-703315; fax: 0361-4321; e-mail: msudarma@unud..ac.id,dayu.giriantari@unud.ac.idpenulis2@unu d..ac.id)
}

Hasil dari pengujian dengan metode SVM-KNN memiliki peningkatan nilai yang cukup signifikan dari metode K-Nearest Neighbour. Metode SVM-KNN juga memiliki selisih waktu Dwi Ardiada: Text Mining Pada Sosial ... komputasi yang tidak signifikan dalam melakukan dua kali klasifikasi daripada metode K-Nearest Neighbour yang hanya melakukan satu kali klasifikasi

Kata Kunci- Emosi, K-Nearest Neighbour, Support Vector Machine, Twitter.

\section{PENDAHULUAN}

Data tidak terstruktur banyak terdapat pada layanan sosial media. Layanan sosial media merupakan penyedia sumber daya yang menyediakan data yang cukup besar. Media sosial banyak menyita perhatian masyarakat karena dianggap dapat menjadi tempat untk berbagi karya, ide, opini tentang isu-isu yang terjadi secara bebas, dan media untuk mengungkapkan berbagai hal mengenai kehidupan pribadinya. Salah satu media sosial yang banyak digunakan masyarakat adalah Twitter.

Twitter layanan jejaring sosial dan mikroblog yang memungkinkan penggunanya untuk mengirim dan membaca pesan berbasis teks hingga 140 karakter, yang dikenal dengan sebutan kicauan (tweet)[1].

Sebuah teks pada tweet tidak hanya menyampaikan keterangan dari suatu informasi, tetapi juga berisi informasi tentang perilaku manusia termasuk emosi. Emosi merupakan keadaan kompleks dari pikiran yang dipengaruhi oleh peristiwa eksternal, perubahan fisiologis, atau hubungan dengan orang lain. Dengan tidak adanya kontak tatap muka untuk mendeteksi ekspresi wajah dan intonasi dalam suara, opsi alternatifnya adalah menguraikan emosi dari teks di layanan sosial media. Studi penelitian pendeteksian emosi telah menyelidiki deteksi emosi dalam prosodi, perubahan keadaan fisiologis, ekspresi wajah dan teks. Namun, ada kekurangan penelitian dalam mendeteksi emosi dari teks dibandingkan dengan area lain dari deteksi emosi [2].

Untuk mendeteksi emosi dari teks pada layanan sosial media twitter dengan data yang tidak terstruktur maka perlu dilakukan analisis teks salah satunya dengan menggunakan Text Mining. Text mining mencoba untuk mengekstrak informasi yang berguna dari sumber data melalui identifikasi dan eksplorasi dari suatu pola menarik. Sumber data berupa sekumpulan dokumen dan pola menarik yang tidak ditemukan dalam bentuk database record, tetapi dalam data teks yang tidak terstruktur.

Beberapa penelititan mengenai deteksi emosi telah dilakukan contohnya padap enelitian yang dilakukan Chaitail G. Patil dan Sandip S.Patil menyebutkan penggunaan metode Support Vector Machine dan dataset ISEAR memiliki akurasi tertinggi yaitu $71.64 \%$ sedangkan Metode Naive Bayes

p-ISSN:1693 - 2951; e-ISSN: 2503-2372 
Classifier akurasinya $60.8 \%$ dan yang terendah pada metode Vector Space Model 34.8\% dalam untuk Ekstraksi Emosi dari Headline News [3]. Namun Pada penelitianm Arifin and Ketut Eddy Purnama melakukan Klasifikasi Emosi Dalam Teks Bahasa Indonesia menggunakan metode K-Nearest Neighbour. Pada penelitian yang dilakukan penulis melakukan klasfikasi emosi pada artikel yang ada diinternet kemudian dilakukan pengujian antara metode Naïve Bayes dengan K-Nearest Neighbour. Hasil dari penelitian tersebut didapat metode KNearest Neighbour menghasilkan nilai akurasi $71.26 \%$ yang lebih tinggi daripada metode Naïve Bayes dengan nilai akurasi $58.01 \%$ [4].

Berdasarkan latar belakang dan beberapa penelitian sebelumnya maka penulis melalui penelitian ini mengusulkan melakukan penelitian implementasi text mining pada Sosial Media untuk mendeteksi emosi pengguna. Metode klasifikasi yang digunakan yaitu metode Support Vector Machine untuk klasifikasi kelas emosi dan metode K-Nearest Neighbour untuk klasifikasi kategori emosi. Metode tersebut digunakan karena metode Support Vector Machine memiliki nilai akurasi tertinggi pada penelitian sebelumnya serta Support Vector Machine secara teoritik dikembangkan untuk problem klasifikasi dengan dua class yang sangat tepat untuk klasifikasi kelas emosi[5]. Sedangkan Metode K-Nearest Neighbour digunakan karena pada penelitian sebelumnya KNearest Neighbour memiliki akurasi yang lebih tinggi daripada metode Naive Bayes dan Metode K-Nearest Neighbour melakukan pelatihannya sangat cepat dan Efektif jika data pelatihan besar yang sangat cocok dengan penggunaan ISEAR dataset [6]. Deteksi emosi berbasis teks seperti yang disebutkan sebelumnya dapat digunakan dalam bisnis, pendidikan, psikologi, dan bidang lain mana pun yang paling penting untuk memahami dan menafsirkan emosi.

\section{METODE PENELITIAN}

Penelititan ini menggunakan metode gabungan SVM dan KNN pada data twitter. Alur metode usulan yang digunakan terlihat pada Gambar 1. Metode SVM polynomial kernel digunakan untuk melakukan klasifikasi pada ISEAR dataset untuk menentukan kelas emosi. Setelah didapatkan label kelas emosi dilakukan seleksi dataset kembali berdasarkan kelas emosi yang telah ditentukan pada tabel kelas emosi[7]. Metode K-NN akan melakukan klasifikasi kembali berdasarkan dataset yang sudah ditentukan kelas emosinya dari metode SVM. K-NN bekerja dengan melakukan perhitungan euclidean distance untuk menentukan label emosi yang memiliki jarak terdekat dengan data uji.

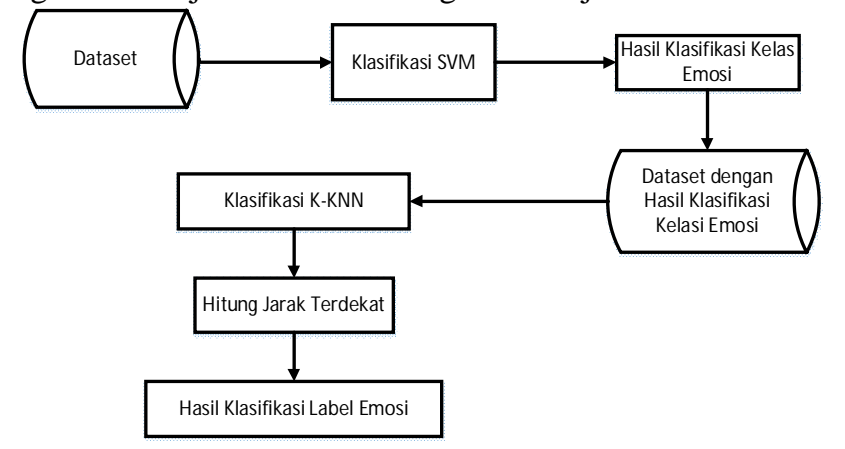

Gambar 1. Metode SVM-KNN
Secara umum proses text mining pada Sosial Media untuk mendeteksi emosi pengguna menggunakan metode SVMKNN dan Dataset ISEAR ditunjukkan pada Gambar 2:

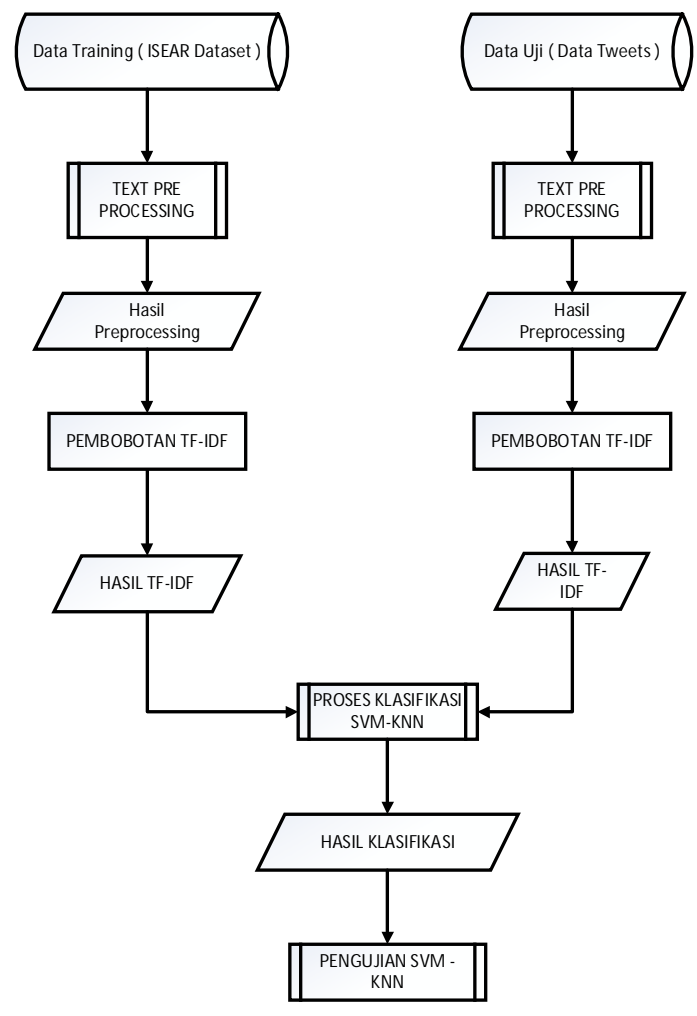

Gambar 2. Proses Metode dan Teknik Analisis Data

Pada Gambar 2. menjelaskan gambaran sistem yang akan berjalan pada penelitian ini. Proses awal dari sistem ini adalah melakukan pengumpulan data pada twiiter dengan menggunakan Stream Twitter API. Setelah melakukan pengumpulan data menggunakan Stream Twitter API kemudian masuk ke Sub Proses Text Preprocessing. Selanjutnya Hasil dari Proses Text Preprocessing adalah melakukan pembobotan menggunakan metode TF - IDF[8]. Pembobotan dilakukan agar bisa dilakukan klasifikasi. Hasil dari pembobotan menggunakan metode TF-IDF kemudian masuk ke sub Proses Klasifikasi menggunakan Metode SVM - KNN untuk mendeteksi emosi dari teks. Proses Selanjutnya dilakukan pengujian terhadap hasil dari klasifikasi sistem. Pengujian dilakukan untuk mendapatkan nilai akurasi, recall dan precision dari pendeteksian yang dilakukan.

Untuk subproses Text preprocessing ditunjuk pada Gambar 3. pada proses ini Data tweet tersebut akan dilakukan tokenizing dengan cara dilakukan pemisahan - pemisahan tiap kata pada setiap data tweet. Proses selanjutnya dilakukan filtering. Pada proses filtering ini dilakukan proses seleksi terhadap kata-kata yang dihasilkan dari proses tokenizing, selanjutnya Algoritma stop list akan membuang kata-kata yang tidak penting seperti kata ganti, kata keterangan, kata sambung, kata depan dan kata sandang. dan algoritma word list akan menyimpan katakata yang penting. Selanjutnya Sistem melakukan proses stemming, Proses Stemming dilakukan untuk mencari kata dasar dari setiap kata yang telah lolos proses filtering. 


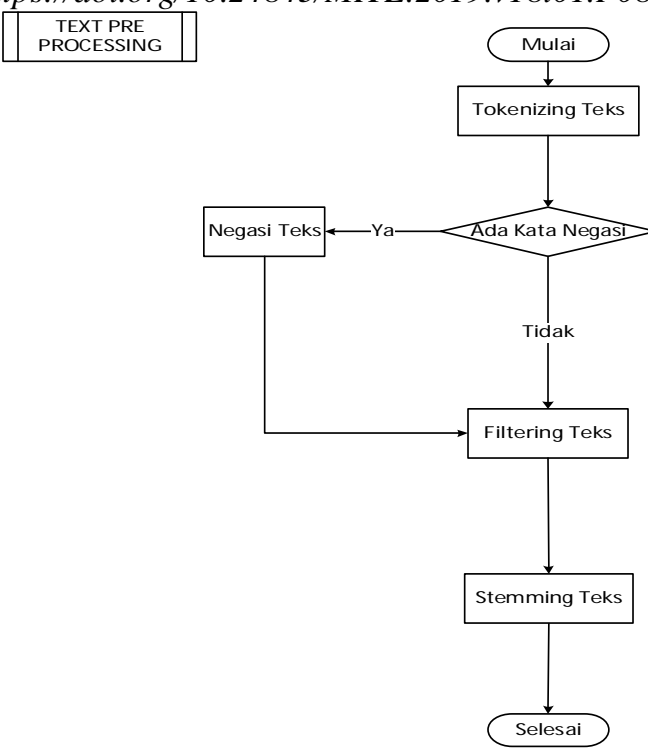

Gambar 3. Sub Proses Text Preprocessing

Selanjutnya Sistem akan melakukan Analisis dan Pembobotan menggunakan Metode TF IDF. Pada Proses Metode TF IDF ini dilakukan penentuan bobot data berdasarkan kemunculan term (istilah). Semakin sering sebuah istilah muncul, semakin tinggi bobot data untuk istilah tersebut, dan sebaliknya. Untuk Sub Proses Klasifikasi SVM -KNN ditunjuk pada Gambar 4.

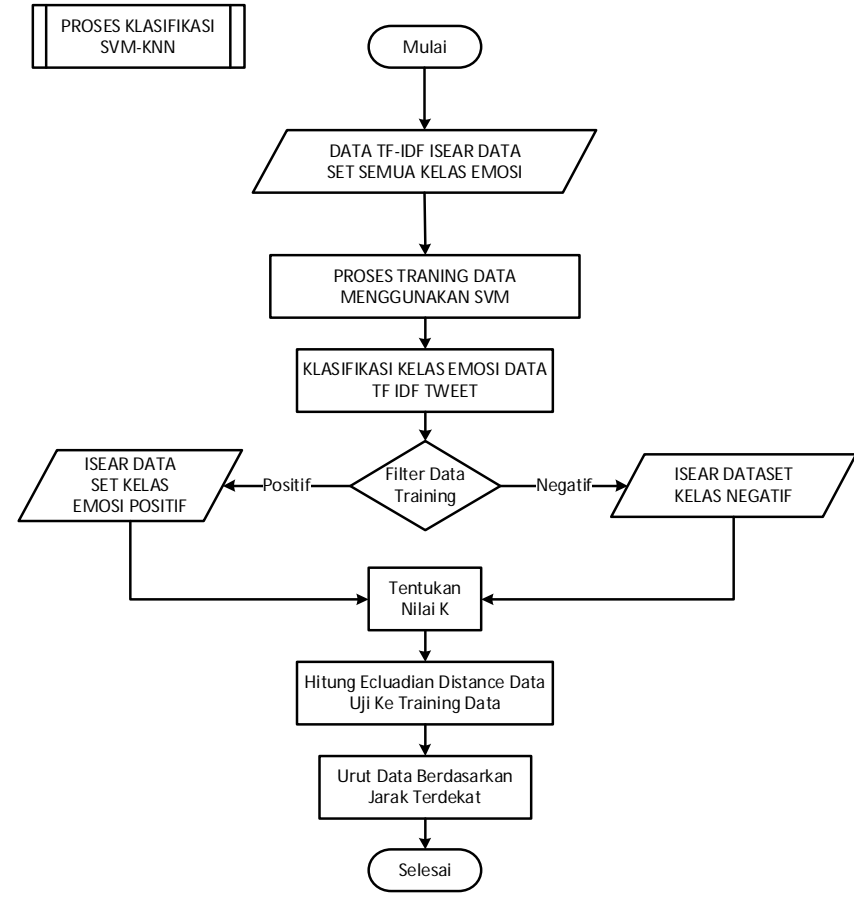

Gambar 4. Sub Proses Klasifikasi SVM-KNN

Pada proses ini Hasil Dari pembobotan TF -IDF pada ISEAR dataset dilakukan Training data menggunakan metode SVM. Selanjutnya Data TF-IDF dari data Tweet dilakukan klasifikasi menggunakan Metode SVM untuk menentukan kelas Emosinya. Hasil dari Klasifikasi SVM akan melakukan filter pada Data Traning pada parameter kelas emosi. Hasil Filter Data Traning digunakan kembali untuk melakukan klasifikasi menggunakan metode KNN. Dengan menggunakan Dwi Ardiada: Text Mining Pada Sosial ...

Metode KNN diperoleh data yang memiliki jarak terdekat yang digunakan untuk mendeteksi emosi pengguna. Hasil dari pengujian ini akan dilakukan evaluasi dengan menghitung recall, precision dan accuracy pada data yang diuji pada penelitian ini.

\section{HASIL DAN PEMBAHASAN}

Aplikasi deteksi emosi pengguna dibuat menggunakan Bahasa pemograman PHP pada Sublime Text 3. Data tweets yang akan diproses disimpan pada table tb_datauji yang nantinya akan dibaca oleh aplikasi deteksi emosi. Jumlah data yang akan diuji sejumlah 294 data tweet. Untuk melakukan pendeteksian emosi memerlukan data latih sebagai proses mesin pembelajaran. Penelitian ini menggunakan ISEAR dataset sebagai data latihnya. Pada Tabel I merupakan salah satu data latih pada ISEAR dataset.

TABEL I

CONTOH DATA LATIH ISEAR DATASET

\begin{tabular}{|c|c|c|}
\hline No & $\begin{array}{c}\text { Label } \\
\text { Indonesia }\end{array}$ & Teks Indonesia \\
\hline & & $\begin{array}{c}\text { Pada hari-hari ketika saya merasa dekat dengan } \\
\text { pasangan saya dan teman-teman lainnya Ketika } \\
\text { saya merasa damai dengan diri sendiri dan juga } \\
\text { mengalami kontak dekat dengan orang-orang } \\
\text { yang sangat saya hargai }\end{array}$ \\
\hline 2 & senang & $\begin{array}{r}\text { Setiap kali saya membayangkan bahwa } \\
\text { seseorang yang saya cintai atau saya dapat } \\
\text { menghubungi penyakit yang serius bahkan } \\
\text { kematian }\end{array}$ \\
\hline 3 & Takut & $\begin{array}{c}\text { Ketika saya jelas diperlakukan dengan tidak } \\
\text { adil dan tidak memiliki kemungkinan untuk } \\
\text { menjelaskan hal ini }\end{array}$ \\
\hline
\end{tabular}

\section{A. Data Uji Twitter}

Pada penelitian ini menggunkanan data uji sejumlah 294 data tweets yang sudah dilabelkan berdasarkan emosi yang ditulis pada hastag tweets dibagian akhir [9]. Data uji pada penelitian ini diambil pada Bulan Agustus 2018 sampai Bulan Oktober 2018 yang hanya berbahasa indonesia saja. Salah satu sampel data uji terlampir pada table II.

TABEL II

CONTOH DATA UJI TWITTER

\begin{tabular}{|c|l|l|l|}
\hline Foto & Nama & \multicolumn{1}{|c|}{ Tweet } & Label \\
\hline & kin & $\begin{array}{l}\text { Ramai gak kahwin time muda } \\
\text { ni. Ramai juga yang bercerai } \\
\text { time muda \#takut }\end{array}$ & takut \\
\hline MF Sam & $\begin{array}{l}\text { bg. } \\
\text { mulut bikin berguna dan } \\
\text { bermanfaat kek,.jgn bau } \\
\text { comberan mulu yg } \\
\text { keluarr...\#jijik }\end{array}$ & jijik \\
\hline Hery & Hutabarat & $\begin{array}{l}\text { Trotoar Jalan Margonda } \\
\text { Sudah Berbulan-bulan } \\
\text { Berlubang } \\
\text { https://t.co/ueRm9NAnaV } \\
\text { @pemkotdepok \#malu }\end{array}$ & Malu \\
\hline
\end{tabular}

p-ISSN:1693 - 2951; e-ISSN: 2503-2372 


\section{B. Tokenizing}

Untuk melakukan text Preprocessing pada penelitian ini dilakukan tahap tokenizing pada suatu data. Pada tokenizing ini menghilangkan karakter simbol dan angka [10]. Berikut hasil tokenizing pada data latih terdapat pada tabel III.

TABEL III

CONTOH HASIL TOKENIZING

\begin{tabular}{|c|c|c|c|}
\hline No. & Label & Teks & Tokenizing \\
\hline 1 & senang & $\begin{array}{l}\text { Pada hari-hari ketika } \\
\text { saya merasa dekat } \\
\text { dengan pasangan } \\
\text { saya dan teman- } \\
\text { teman lainnya } \\
\text { Ketika saya merasa } \\
\text { damai dengan diri } \\
\text { sendiri dan juga } \\
\text { mengalami kontak } \\
\text { dekat dengan orang- } \\
\text { orang yang sangat } \\
\text { saya hargai }\end{array}$ & $\begin{array}{c}\text { Pada hari hari ketika } \\
\text { saya merasa dekat } \\
\text { dengan pasangan saya } \\
\text { dan teman teman } \\
\text { lainnya Ketika saya } \\
\text { merasa damai dengan } \\
\text { diri sendiri dan juga } \\
\text { mengalami kontak dekat } \\
\text { dengan orang orang } \\
\text { yang sangat saya hargai }\end{array}$ \\
\hline 2 & Takut & $\begin{array}{c}\text { Setiap kali saya } \\
\text { membayangkan } \\
\text { bahwa seseorang } \\
\text { yang saya cintai atau } \\
\text { saya dapat } \\
\text { menghubungi } \\
\text { penyakit yang serius } \\
\text { bahkan kematian }\end{array}$ & $\begin{array}{c}\text { Setiap kali saya } \\
\text { membayangkan bahwa } \\
\text { seseorang yang saya } \\
\text { cintai atau saya dapat } \\
\text { menghubungi penyakit } \\
\text { yang serius bahkan } \\
\text { kematian }\end{array}$ \\
\hline 3 & marah & $\begin{array}{c}\text { Ketika saya jelas } \\
\text { diperlakukan dengan } \\
\text { tidak adil dan tidak } \\
\text { memiliki } \\
\text { kemungkinan untuk } \\
\text { menjelaskan hal ini }\end{array}$ & $\begin{array}{c}\text { Ketika saya jelas } \\
\text { diperlakukan dengan } \\
\text { tidak adil dan tidak } \\
\text { memiliki kemungkinan } \\
\text { untuk menjelaskan hal } \\
\text { ini }\end{array}$ \\
\hline
\end{tabular}

\section{Negasi}

Pada Proses Negasi pada Text Preprocessing diperlukan Data yang sudah melewati proses tokenizing. Pada Proses Negasi melakukan transformasi teks yang diawali kata tidak kemudian dilakukan antonim berdasarkan data negasi yang sudah diinputkan. Berikut hasil proses Negasi data Latih dalam tabel IV.

TABEL IV

CONTOH HASIL NEGASI

\begin{tabular}{|c|c|c|c|}
\hline No & Label & Teks Tokenizing & Hasil Negasi \\
\hline 1 & senang & $\begin{array}{l}\text { Pada hari hari ketika } \\
\text { saya merasa dekat } \\
\text { dengan pasangan } \\
\text { saya dan teman } \\
\text { teman lainnya Ketika } \\
\text { saya merasa damai } \\
\text { dengan diri sendiri } \\
\text { dan juga mengalami } \\
\text { kontak dekat dengan } \\
\text { orang orang yang } \\
\text { sangat saya hargai }\end{array}$ & $\begin{array}{c}\text { pada hari hari ketika } \\
\text { saya merasa dekat } \\
\text { dengan pasangan saya } \\
\text { dan teman teman } \\
\text { lainnya ketika saya } \\
\text { merasa damai dengan } \\
\text { diri sendiri dan juga } \\
\text { mengalami kontak dekat } \\
\text { dengan orang orang } \\
\text { yang sangat saya hargai }\end{array}$ \\
\hline 2 & Takut & $\begin{array}{c}\text { Setiap kali saya } \\
\text { membayangkan } \\
\text { bahwa seseorang } \\
\text { yang saya cintai atau } \\
\text { saya dapat } \\
\text { menghubungi } \\
\text { penyakit yang serius }\end{array}$ & $\begin{array}{c}\text { setiap kali saya } \\
\text { membayangkan bahwa } \\
\text { seseorang yang saya } \\
\text { cintai atau saya dapat } \\
\text { menghubungi penyakit } \\
\text { yang serius bahkan } \\
\text { kematian }\end{array}$ \\
\hline
\end{tabular}

\begin{tabular}{|c|c|c|c|}
\hline & & bahkan kematian & \\
\hline 3 & marah & $\begin{array}{c}\text { Ketika saya jelas } \\
\text { diperlakukan dengan } \\
\text { tidak adil dan tidak } \\
\text { memiliki } \\
\text { kemungkinan untuk } \\
\text { menjelaskan hal ini }\end{array}$ & $\begin{array}{c}\text { ketika saya jelas } \\
\text { diperlakukan dengan } \\
\text { timpang dan tidak } \\
\text { memiliki kemungkinan } \\
\text { untuk menjelaskan hal } \\
\text { ini }\end{array}$ \\
\hline
\end{tabular}

\section{Filtering}

Pada Proses Filtering pada Text Preprocessing diperlukan Data yang sudah melewati proses negasi. Pada Proses Negasi melakukan penghapusan kata - kata yang ada pada daftar data stoplist. Berikut hasil proses Filtering data Latih dalam tabel V.

TABEL V

CONTOH HASIL FILTERING

\begin{tabular}{|c|c|c|c|}
\hline No & Label & Teks Negasi & Hasil Filtering \\
\hline 1 & senang & $\begin{array}{l}\text { pada hari hari ketika saya } \\
\text { merasa dekat dengan } \\
\text { pasangan saya dan teman } \\
\text { teman lainnya ketika saya } \\
\text { merasa damai dengan diri } \\
\text { sendiri dan juga } \\
\text { mengalami kontak dekat } \\
\text { dengan orang orang yang } \\
\text { sangat saya hargai }\end{array}$ & $\begin{array}{l}\text { pasangan teman } \\
\text { teman damai } \\
\text { mengalami kontak } \\
\text { orang orang hargai }\end{array}$ \\
\hline 2 & Takut & $\begin{array}{c}\text { setiap kali saya } \\
\text { membayangkan bahwa } \\
\text { seseorang yang saya } \\
\text { cintai atau saya dapat } \\
\text { menghubungi penyakit } \\
\text { yang serius bahkan } \\
\text { kematian }\end{array}$ & $\begin{array}{l}\text { kali membayangkan } \\
\text { cintai menghubungi } \\
\text { penyakit serius } \\
\text { kematian }\end{array}$ \\
\hline 3 & marah & $\begin{array}{l}\text { ketika saya jelas } \\
\text { diperlakukan dengan } \\
\text { timpang dan tidak } \\
\text { memiliki kemungkinan } \\
\text { untuk menjelaskan hal ini }\end{array}$ & $\begin{array}{l}\text { diperlakukan } \\
\text { timpang tidak } \\
\text { memiliki }\end{array}$ \\
\hline
\end{tabular}

\section{E. Stemming}

Pada Proses Stemming pada Text Preprocessing diperlukan Data yang sudah melewati proses filtering. Pada Proses Stemming melakukan pencarian kata dasar yang ada pada daftar data kata dasar. Proses pencarian kata dasar menerapkan Algoritma Nazief Stemmer[11]. Berikut hasil proses Stemming data Latih dalam tabel VI.

TABEL VI

CONTOH HASIL STEMMING

\begin{tabular}{|c|c|c|c|}
\hline No & Label & Teks Filtering & Hasil Stemming \\
\hline & & $\begin{array}{c}\text { pasangan teman teman } \\
\text { damai mengalami } \\
\text { kontak orang orang } \\
\text { hargai }\end{array}$ & $\begin{array}{c}\text { pasang teman teman } \\
\text { damai alami kontak } \\
\text { orang orang harga }\end{array}$ \\
\hline 2 & senang & $\begin{array}{c}\text { kali membayangkan } \\
\text { cintai menghubungi } \\
\text { penyakit serius kematian }\end{array}$ & $\begin{array}{c}\text { kali bayang cinta } \\
\text { hubung sakit serius } \\
\text { mati }\end{array}$ \\
\hline 3 & marah & $\begin{array}{c}\text { diperlakukan timpang } \\
\text { tidak memiliki }\end{array}$ & $\begin{array}{c}\text { laku timpang tidak } \\
\text { milik }\end{array}$ \\
\hline
\end{tabular}

\section{F. Pembobotan TF-IDF}

Sebelum Pada klasifikasi emosi data yang sudah dilakukan text preprocessing memerlukan pembobotan untuk dapat 
diklasifikasi. Dalam penelitian ini data latih akan dilakukan pembobotan dengan menggunakan metode TF-IDF. Pembobotan TF IDF bisa dilakukan apabila ada sebuah data uji yang digunakan sebagai query dalam metode TF-IDF. berikut pada Gambar 5. akan diperlihatkan proses aplikasi dalam melakukan pembobotan menggunakan metode TF IDF

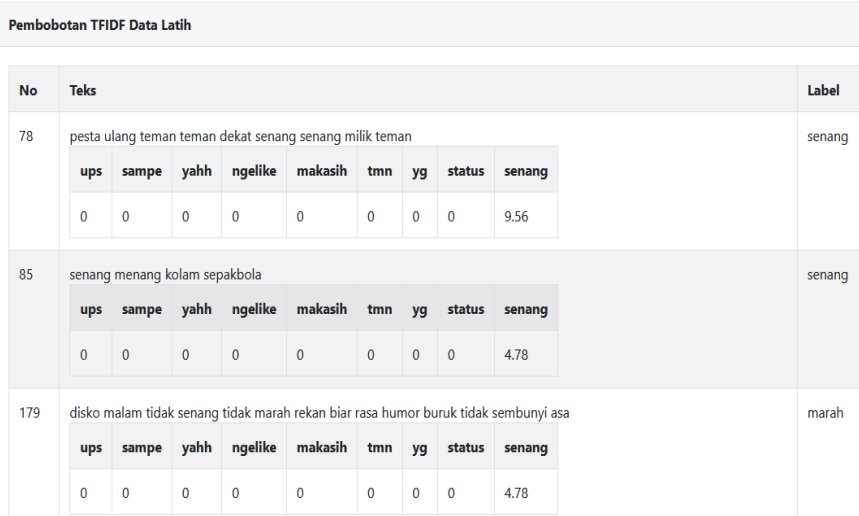

Gambar 5. Pembobotan TF IDF

\section{G. Klasifikasi Emosi}

Dari Hasil Pembobotan Menggunakan Metode TF IDF dilakukan proses Klasifikasi untuk mendeteksi emosi. Proses Klasifikasi pada penelitian ini melakukan perbandingan Klasifikasi sekali metode K-Nearest Neighbour dengan dua kali Klasifikasi yaitu dengan metode Support Vector Machine (SVM) untuk menentukan Kelas Emosi setelah itu diklasifikasi kembali dengan Metode K-Nearest Neighbour untuk mendeteksi kategori emosinya. Pada metode K-Nearest Neighbour menggunakan nilai $\mathrm{K}=6$. Pada Metode Support Vector Machine menggunakan kernel polynomial non Linier Kernel dengan parameter tetap yang di default $\mathrm{p}=2$ dan $b=1$. Berikut hasil klasifikasi emosi pada kedua metode yang dibandingkan terlampir pada Gambar 6.

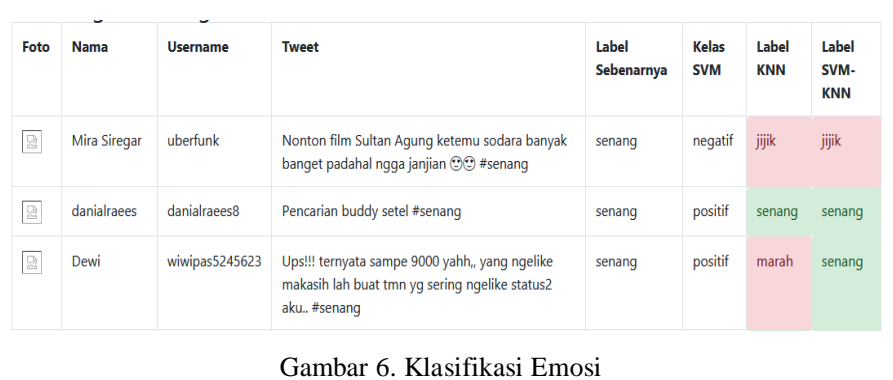

\section{H. Evaluasi Pengujian}

Pada Hasil Klasifikasi Emosi yang telah dilakukan penelitian ini melakukan Evaluasi pengujian dengan menggunakan metode cofusion matrix untuk menentukan Recall, Precision dan Accuracy pada sebuah klasifikasi yang dilakukan. Klasifikasi yang dilakukan pada penelitian ini menggunakan data uji sejumlah 294 data dan dengan data latih sebanyak 6561 dari ISEAR dataset. Data testing diperoleh dari media sosial twitter dengan menggunakan Twitter Api pada Bulan Agustus 2018 Sampai Tanggal 2 Oktober 2018. Data Uji dilabelkan berdasarkan hastag berdasarkan kategori emosi. Terdapat 9 data testing pada Dwi Ardiada: Text Mining Pada Sosial ... kategori senang, 22 data testing pada kategori takut, 35 data testing pada kategori marah, 187 data testing pada kategori sedih, 17 data testing pada kategori jijik, 24 data testing pada kategori malu.

Sedangkan pada data latih ISEAR dataset terdapat 1091 data latih pada kategori senang, 1093 data latih pada kategori takut, 1094 data latih pada kategori marah, 1094 data latih pada kategori sedih, 1094 data latih pada kategori jijik dan 1094 data latih pada kategori malu. Dari data tersebut diklasifikasi untuk mendeteksi emosi dengan metode yang diusulkan untuk melakukan perbandingan. Dari tahap evaluasi pengajuan yang dilakukan maka didapatkan hasil pengujian klasifikasi emosi. Berikut pada tabel VII merupakan hasil pengujian menggunakan metode K-Nearest Neighbour.

TABEL VII

HASIL EVALUASI KESELURUHAN KATEGORI EMOSI METODE K-NN

\begin{tabular}{|c|c|c|c|}
\hline $\begin{array}{c}\text { Kategori } \\
\text { Emosi }\end{array}$ & Precision & Recall & Accuracy \\
\hline jijik & 0.2727 & 0.5294 & 0.8912 \\
\hline Malu & 0.2333 & 0.2917 & 0.8639 \\
\hline marah & 0.2549 & 0.3714 & 0.7959 \\
\hline Sedih & 0.9028 & 0.3476 & 0.5612 \\
\hline senang & 0.0741 & 0.4444 & 0.8129 \\
\hline Takut & 0.3148 & 0.7727 & 0.8571 \\
\hline Rata-Rata & 0.3421 & 0.4595 & 0.797 \\
\hline
\end{tabular}

Dari hasil pengujian keseluruhan dalam klasifikasi emosi dengan metode K-Nearest Neighbour nilai rata-rata precision yaitu 0.3421. Sedangkan nilai recall yaitu 0.4595 dan pada nilai accuracy yaitu pada 0.797 . Sedangkan pada hasil pengujian menggunakan metode SVM-KNN didapat hasil pada table VIII seperti berikut :

TABEL VIII

HASIL EVALUASI KESELURUHAN KATEGORI EMOSI METODE SVM K-NN

\begin{tabular}{|c|c|c|c|}
\hline Kategori & Precision & Recall & Accuracy \\
\hline jijik & 0.1591 & 0.4118 & 0.8401 \\
\hline Malu & 0.3333 & 0.3333 & 0.8912 \\
\hline marah & 0.2923 & 0.5429 & 0.7891 \\
\hline Sedih & 0.881 & 0.3957 & 0.5816 \\
\hline senang & 0.8333 & 0.5556 & 0.983 \\
\hline Takut & 0.2394 & 0.7727 & 0.7993 \\
\hline Rata-Rata & 0.4564 & 0.502 & 0.8141 \\
\hline
\end{tabular}

Dari hasil pengujian keseluruhan dalam klasifikasi emosi dengan metode SVM-KNN nilai rata-rata precision yaitu 0.4564. Sedangkan nilai recall yaitu 0.502 dan pada nilai accuracy yaitu pada 0.8141. Perbandingan Evaluasi Hasil Pengujian Dari Metode SVM-KNN dengan K-NN menunjukkan adanya perbedaan nilai precision, recall dan accuracy yang disebabkan dari pengurangan data training pada klasifikasi SVM-KNN berdasarkan hasil klasifikasi Kelas Emosi dengan metode SVM. Apabila kelas Emosinya

p-ISSN:1693 - 2951; e-ISSN: 2503-2372 
Positif maka Klasifikasi selanjutnya hanya menggunakan kategori emosi yang memiliki kelas positif Demikian juga sebaliknya. Dari hal tersebut juga mempengaruhi Klasifikasi K-NN pada nilai K. Selain itu hasil pengujian tersebut juga menunjukkan perbendaan nilai kesesuaian dalam Klasifikasi Emosi pada Gambar 8. Berikut hasil Evaluasi Kesesuaian Klasifikasi Selurh Emosi.

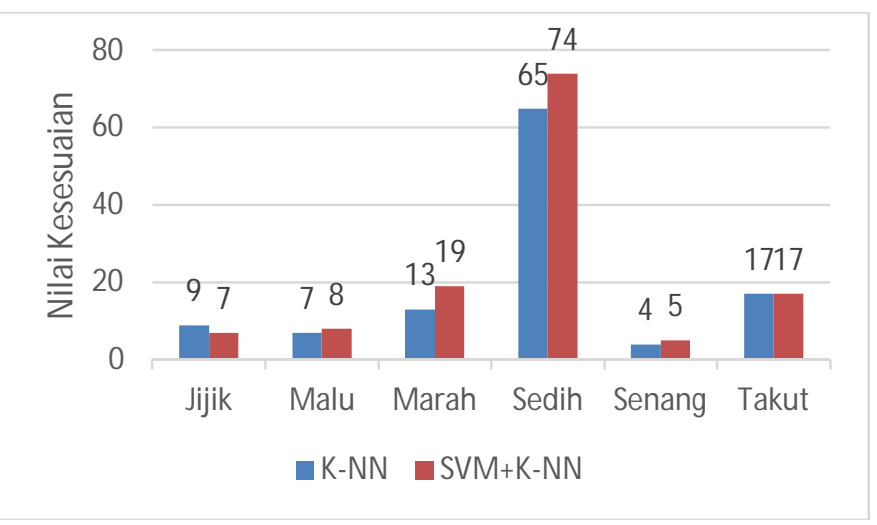

Gambar 7 Grafik Hasil Kesesuaian Keseluruhan Kategori Emosi

Selain itu dilakukan pengujian Komputasi Waktu yang diperlukan dalam klasifikasi emosi. Dari pengujian komputasi waktui didapatkan hasil pada table IX sebagai berikut :

TABEL IX

HASIL EVALUASI WAKTU KOMPUTASI KATEGORI EMOSI

\begin{tabular}{|c|c|c|}
\hline \multirow{2}{*}{ Kategori Emosi } & \multicolumn{2}{|c|}{$\begin{array}{c}\text { Waktu Komputasi Klasifikasi ( dalam } \\
\text { detik ) }\end{array}$} \\
\cline { 2 - 3 } & K-NN & SVM-K-NN \\
\hline Jijik & \pm 5.0006 & \pm 5.4353 \\
\hline Malu & \pm 9.1735 & \pm 11.5552 \\
\hline Marah & \pm 14.7334 & \pm 15.8777 \\
\hline Sedih & \pm 72.8879 & \pm 77.572 \\
\hline Senang & \pm 3.3227 & \pm 3.7488 \\
\hline Takut & \pm 7.8605 & \pm 8.8471 \\
\hline
\end{tabular}

Pada Pengujian Komputasi waktu Metode SVM-KNN memiliki selisih waktu yang tidak signifikan dari metode KNN itu disebabkan karena metode SVM-KNN melakukan dua kali klasifikasi yaitu klasifikasi pertama menggunakan Metode SVM dan Klasifikasi kedua menggunakan Metode KNN yang menggunakan data latih berdasakan hasil dari klasifikasi SVM.

\section{KESIMPULAN}

Berdasarkan uji coba yang telah dilakukan dalam penelitian ini dapat disimpulkan beberapa hal sebagai berikut:

1. Penelitian ini menunjukkan hasil klasifikasi emosi dengan metode Support Vector Machine dan KNearest Neighbour mengalami peningkatan nilai presisi, recall , accuracy dan kesesuaian yang signifikan dibandingkan dengan metode K-Nearest Neighbour pada klasifikasi emosi. Hal ini terlihat dari hasil pengujian yang dilakukan dalam mendeteksi emosi dengan metode Support Vector Machine dan K-Nearest Neighbour mendapatkan hasil dengan nilai rata-rata precision sebesar 0.4564.nilai recall sebesar 0.502 dan pada nilai accuracy sebesar 0.8104 dalam melakukan klasifikasi emosi sedangkan dari metode K-Nearest Neighbour mendapatkan hasil dengan nilai rata-rata precision sebesar 0.3421.nilai recall sebesar 0.4595 dan pada nilai accuracy sebesar 0.797 .

2. Metode dua kali klasifikasi Support Vector Machine dan K-Nearest Neighbour memiliki selisih waktu yang tidak signifikan dengan metode K-Nearest Neighbour yang melakukan satu kali klasifikasi. Hal ini terlihat dari hasil komputasi waktu klasifikasi yang dilakukan. Itu disebabkan karena adanya pengurangan data training pada klasifikasi SVMKNN yang menggunakan acuan hasil klasifikasi Kelas Emosi dengan metode Support Vector Machine. Apabila kelas Emosinya Positif maka Klasifikasi selanjutnya hanya menggunakan data training dengan kategori emosi yang memiliki kelas positif saja demikian juga sebaliknya.

\section{REFERENSI}

[1] H. Kwak, C. Lee, H. Park, and S. Moon, "What is Twitter , a Social Network or a News Media?," 19th Int. Conf. World Wide Web, pp. 591-600, 2010.

[2] V. P. Haji Binali, Chen Wu, "Computational Approaches for Emotion Detection in Text," IEEE Int. Conf. Digit. Ecosyst. Technol. (IEEE DEST 2010), 2010.

[3] C. G. Patil and S. S. Patil, "Use of Porter Stemming Algorithm and SVM for Emotion Extraction from News Headlines," Int. J. Electron. Commun. Soft Comput. Sci. Eng., vol. 2, no. 7, pp. 22779477, 2013.

[4] Arifin, "Classification of Emotions in Indonesian TextsUsing K-NN Method," Int. J. Inf. Electron. Eng., 2012.

C. Cortes and V. Vapnik, "Support vector machine," Mach. Learn., pp. 1303-1308, 1995.

R. I. Ndaumanu and M. R. Arief, Kusrini, "Analisis Prediksi Tingkat Pengunduran Diri Mahasiswa dengan Metode K-Nearest Neighbor," Jatisi, vol. 1, no. 1, pp. 1-15, 2014.

I. N. W. Tirtayani, Luh Ayu, Noce Maylani Asril, "Perkembangan Sosial Emosional pada Anak Usia Dini," Univ. Terbuka Repos., pp. 1-43, 2013.

[8] N. G. Yudiarta, M. Sudarma, and W. G. Ariastina, "Pengelompokan Berita Pada Unstructured Textual Data," vol. 17, no. 3, pp. 339-344, 2018.

[9] A. P. Sujana, "Memanfaatkan Big Data Untuk Mendeteksi Emosi," Tek. Komput. Unikom, vol. 2, no. 2, pp. 1-4, 2013.

[10] N. L. Ratniasih, M. Sudarma, N. Gunantara, and A. A. U. Sistem, "Penerapan Text Mining dalam Spam Filtering untuk Aplikasi Chat," Teknol. Elektro, vol. 16, no. 3, pp. 13-18, 2017.

[11] M. Adriani, J. Asian, B. Nazief, and H. E. Williams, "Stemming Indonesian: A Confix Stripping Approach," ACM Trans. Asian Lang. Inf. Process., vol. 6, no. 4, pp. 1-33, 2007. 